\title{
Practical application of the multi-model approach in the study of complex systems
}

\author{
Anna V. Korolkova, ${ }^{1, *}$ Dmitry S. Kulyabov, ${ }^{1,2, \dagger}$ and Michal Hnatič ${ }^{3,4,5, \ddagger}$ \\ ${ }^{1}$ Department of Applied Probability and Informatics, \\ Peoples' Friendship University of Russia (RUDN University), \\ 6 Miklukho-Maklaya St, Moscow, 117198, Russian Federation \\ ${ }^{2}$ Laboratory of Information Technologies \\ Joint Institute for Nuclear Research \\ 6 Joliot-Curie, Dubna, Moscow region, 141980, Russian Federation \\ ${ }^{3}$ Department of Theoretical Physics, SAS, Institute of Experimental Physics, \\ Watsonova 47, 04001 Košice, Slovak Republic \\ ${ }^{4}$ Pavol Jozef Šafárik University in Košice (UPJঙ̌), \\ Šrobárova 2, 04180 Košice, Slovak Republic \\ ${ }^{5}$ Bogoliubov Laboratory of Theoretical Physics \\ Joint Institute for Nuclear Research \\ 6 Joliot-Curie, Dubna, Moscow region, 141980, Russian Federation
}

\begin{abstract}
Different kinds of models are used to study various natural and technical phenomena. Usually, the researcher is limited to using a certain kind of model approach, not using others (or even not realizing the existence of other model approaches). The authors believe that a complete study of a certain phenomenon should cover several model approaches. The paper describes several model approaches which we used in the study of the random early detection algorithm for active queue management. Both the model approaches themselves and their implementation and the results obtained are described.
\end{abstract}

Keywords: active queue management, mathematical modeling, simulation, surrogate modeling, stochastic systems

\footnotetext{
*korolkova-av@rudn.ru

† kulyabov-ds@rudn.ru

¥ hnatic@saske.sk
} 


\section{INTRODUCTION}

Scientific research is easy to start but difficult to complete. Our study of the Random Early Detection (RED) algorithm stood out from the study of approaches and mechanisms of traffic control in data transmission networks. But the further we went, the less satisfied we were with the results. The originally constructed mathematical model seemed to us somewhat artificial and non-extensible. To build a more natural mathematical model from first principles, we have developed a method of stochastization of one-step processes. To verify the mathematical model, we have built physical and simulation models. To conduct optimization studies, we began to build a surrogate model for the RED algorithm. At the last we came to an understanding that all of our models form some kind of emergent structure, with the help of which we can investigate various phenomena - stochastic and statistical systems in particular.

In this paper, we try to present our understanding of the multi-model approach to modeling.

\section{MODEL APPROACHES}

Modeling as a discipline encompasses different types of model approaches. From our point of view, these approaches can be schematically described in a unified manner (see Fig. 1). In this case, the research structure consists of operational and theoretical parts. The operational parts are represented by procedures of the system preparation and measurement. It is also common to describe the operational part as input and output data.

The theoretical part consists of two layers: a model layer and an implementation layer. The implementation layer describes the specific structure of the evolution of the system. Depending on the type of implementation, different types of models can be obtained: a mathematical model (implementation - mathematical expressions), a simulation model (implementation - an algorithm), a physical model (implementation - an analog system), a surrogate model (implementation - approximation of behavior). Each type of model has its area of applicability, its advantages and disadvantages. The use of the entire range of models allows the most in-depth and comprehensive study of the modeled system.

\section{RED ACTIVE QUEUE MANAGEMENT ALGORITHM}

Random Early Detection (RED) algorithm is at the heart of several mechanisms to prevent and control congestion in router queues. Its main purpose is to smooth out temporary bursts of traffic and prevent prolonged network congestion by notifying traffic sources about the need to reduce the intensity of information transmission.

The operation of a module implementing a RED-type algorithm can be schematically represented as follows.

When a packet of transmitted data enters the system, it enters the reset module. The decision to remove the package is made based on the value of the $p(\hat{q})$ function received from the control unit. The function $p(\hat{q})$ depends on the exponentially weighted moving average of the queue length $\hat{q}$, also calculated by the ontrol unit based on the current value of the queue length $q$.

The classic RED algorithm is discussed in detail in [1]. Only the formulas for calculating the reset function $p(\hat{q})$ and the exponentially weighted moving average queue length $\hat{q}$ are given here. The use of $\hat{q}$ is associated with the need to smooth outliers of the instantaneous queue length $q$.

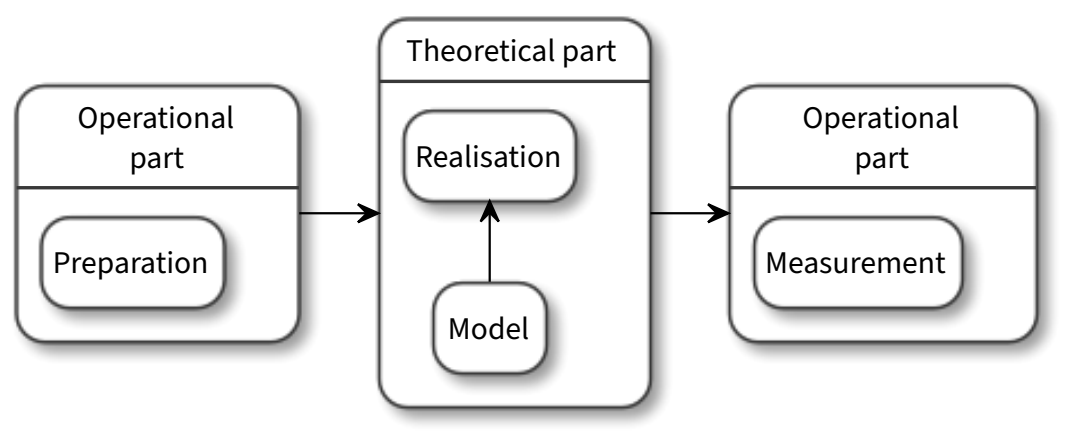

Figure 1. Generic structure of the model approach 


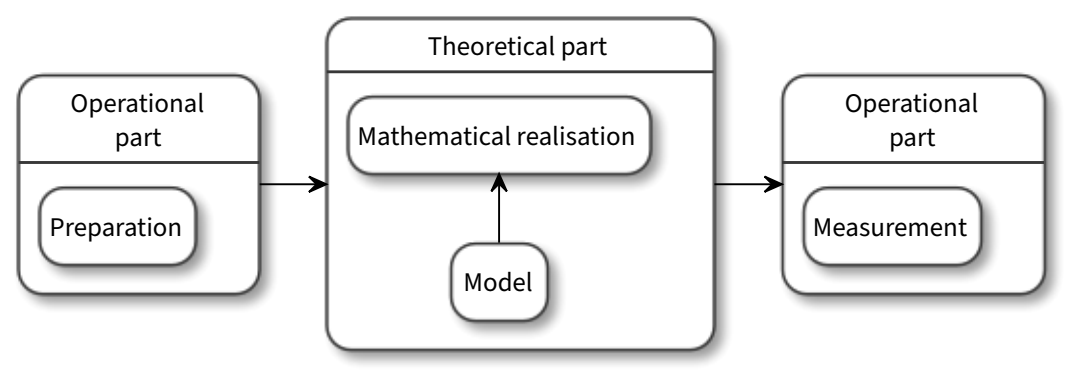

Figure 2. Generic structure of the mathematical model

To calculate $\hat{q}$, the recurrent formula for exponentially weighted moving average (EWMA) is used:

$$
\hat{q}_{k+1}=\left(1-w_{q}\right) \hat{q}_{k}+w_{q} q_{k}, \quad k=0,1,2, \ldots,
$$

where $w_{q}, 0<w_{q}<1$ is the weight coefficient of the exponentially weighted moving average:

$$
w_{q}=1-e^{-1 / C},
$$

where $C$ is the channel bandwidth (packets per second).

The $p(\hat{q})$ packet discard function linearly depends on the $\hat{q}$, the minimum $q_{\min }$ and maximum $q_{\max }$ thresholds and the maximum discard parameter $p_{\max }$, which sets the maximum packet discard level when $\hat{q}$ reaches the value $q_{\max }$, and the function $p(\hat{q})$ is calculated as follows:

$$
p(\hat{q})= \begin{cases}0, & 0<\hat{q} \leqslant q_{\min }, \\ \frac{\hat{q}-q_{\min }}{q_{\max }-q_{\min }} p_{\max }, & q_{\min }<\hat{q} \leqslant q_{\max }, \\ 1, & \hat{q}>q_{\max } .\end{cases}
$$

The drop function (1) describes the classic RED algorithm. And the main effort in the design of new algorithms like RED is directed at various modifications of the type of the drop function.

Since the complete simulated system consists of interoperable TCP and RED algorithms, it is necessary to simulate the evolution of the TCP source as well. Since the original model was based on the TCP Reno protocol, we simulated this particular protocol.

TCP uses a sliding window mechanism to deal with congestion. The implementation of this mechanism depends on the specific TCP protocol standard.

In TCP Reno the congestion control mechanism consists of the following phases: slow start, congestion avoidance, fast transmission, and fast recovery. The dynamics of the congestion window (CWND) size depends on the specific phase.

TCP Reno monitors two types of packet loss:

- Triple Duplicate ACK (TD). Let the $n$-th packet not to be delivered, and the subsequent packets $(n+1, n+2$, etc.) are delivered. For each packet delivered out of order (for $n+1, n+2$, etc.), the receiver sends an ACK message for the last undelivered ( $n$-th) packet. Upon receipt of three such packets, the source resends the $n$-th packet. Besides, the window size is reduced by 2 times $c w n d \rightarrow c w n d / 2$.

- Timeout (TO). When a packet is sent, the timeout timer is started. Each time a confirmation is received, the timer is restarted. The window is then set to the initial value of the overload window. The first lost packet is resent. The protocol enters the slow start phase.

The general congestion control algorithm is of the AIMD type (Additive Increase, Multiplicative Decrease) - an additive increase of the window size and its multiplicative decrease.

\section{MATHEMATICAL MODEL}

The most rigorous research is usually based on a mathematical model (see Fig. 2). In this case, the model layer is realized through mathematical expressions describing the evolution of the system. 
There are several approaches to modeling RED-type algorithms. The most famous approach is modeling using the automatic control theory approach [2-4]. To us, this approach seems somewhat artificial and inconsistent. We prefer to do our modeling from first principles.

We have developed a method of stochastization of one-step processes, which allows us to obtain models from first principles. Moreover, the resulting model models are immanently stochastic [5-7]. Our model of interaction between the TCP source and the RED algorithm is based on these methods and is mathematically represented in the form of stochastic differential equations with Wiener and Poisson processes [8-10].

We will use the following notation. $W(t)$ is the TCP Reno window size, $Q(t)$ is the queue size, $T:=T(Q(t))$ is the round-trip time (taking into account equipment delays), $t$ is the time, $C$ is the queue service intensity, $\hat{Q}(t)$ is the Exponentially Weighted Moving-Average (EWMA) [1]:

$$
\hat{Q}(t)=\left(1-w_{q}\right) \hat{Q}(t)+w_{q} Q(t),
$$

where $w_{q}, 0<w_{q}<1$ is the weight coefficient.

We used the method of stochastization of one-step processes to obtain the Fokker-Planck and Langevin equations for the stochastic processes $W(t)$ and $Q(t)$.

The kinetic equations will be:

$$
\left\{\begin{array}{l}
0 \stackrel{\frac{1}{W(t)}}{\longrightarrow} W(t), \\
W(t) \stackrel{\frac{1}{2} \frac{\mathrm{d} N(t)}{\mathrm{d} t}}{\longrightarrow} 0, \\
0 \stackrel{\frac{W(t)}{T}}{\longrightarrow} Q(t), \\
0 \stackrel{-C}{\longrightarrow} Q(t),
\end{array}\right.
$$

where $\mathrm{d} N(t)$ is the Poisson process [3].

Let us write down the Fokker-Planck equations corresponding to the kinetic equations (2):

$$
\begin{gathered}
\frac{\partial w(t)}{\partial t}=-\frac{\partial}{\partial W(t)}\left[\left(\frac{1}{W(t)}-\frac{W(t)}{2} \frac{\mathrm{d} N(t)}{\mathrm{d} t}\right) w(t)\right]+ \\
+\frac{1}{2} \frac{\partial^{2}}{\partial W^{2}(t)}\left[\left(\frac{1}{W(t)}+\frac{W(t)}{2} \frac{\mathrm{d} N(t)}{\mathrm{d} t}\right) w(t)\right], \\
\frac{\partial q(t)}{\partial t}=-\frac{\partial}{\partial Q(t)}\left[\left(\frac{W(t)}{T}-C\right) q(t)\right]+ \\
+\frac{1}{2} \frac{\partial^{2}}{\partial Q^{2}(t)}\left[\left(\frac{W(t)}{T}-C\right) q(t)\right]
\end{gathered}
$$

where $w(t)$ is the density of the random process $W(t), q(t)$ is the density of the random process $Q(t)$.

The Langevin equations corresponding to the equations (3) have the form:

$$
\left\{\begin{array}{l}
\mathrm{d} W(t)=\frac{1}{T} \mathrm{~d} t-\frac{W(t)}{2} \mathrm{~d} N(t)+\sqrt{\frac{1}{T}+\frac{W(t)}{2}} \frac{\mathrm{d} N(t)}{\mathrm{d} t} \mathrm{~d} V^{1}(t), \\
\mathrm{d} Q(t)=\left(\frac{W(t)}{T}-C\right) \mathrm{d} Q(t)+\sqrt{\frac{W(t)}{T}-C} \mathrm{~d} V^{2}(t),
\end{array}\right.
$$

where $\mathrm{d} V^{1}(t)$ is the Wiener process corresponding to the random process $W(t), \mathrm{d} V^{2}(t)$ is the Wiener process corresponding to the random process $Q(t)$.

The equations (4) are supplemented by the constraint equation (written in differential form for convenience):

$$
\frac{\mathrm{d} \hat{Q}(t)}{\mathrm{d} t}=w_{q} C(Q(t)-\hat{Q}(t)) .
$$

This mathematical model can be investigated both in the form of stochastic differential equations and by writing them down in moments. The equation in moments is naturally easier to study. 


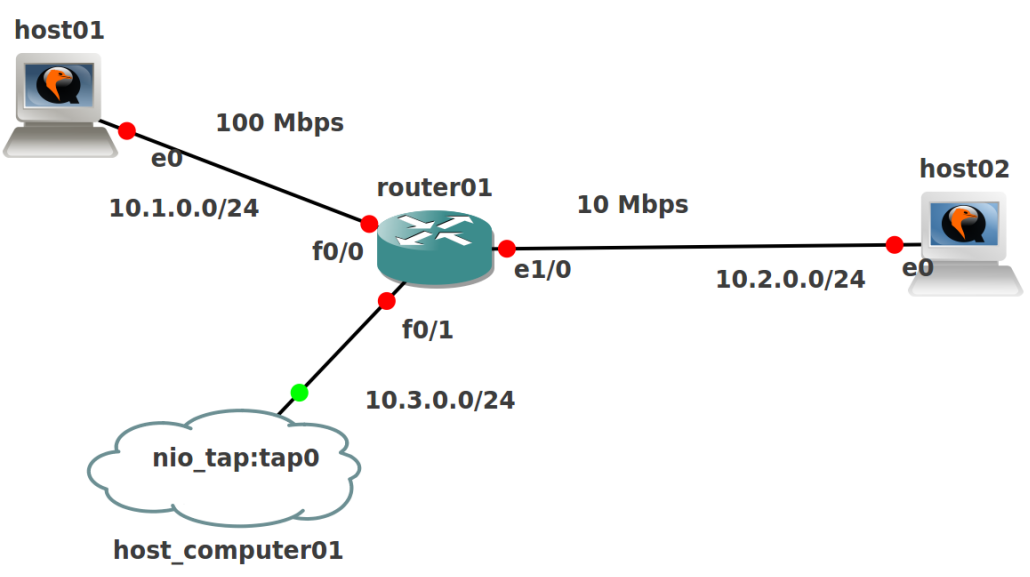

Figure 3. Virtual stand for studying the functioning of the RED algorithm. host01 is the packet source; host02 is the recipient.

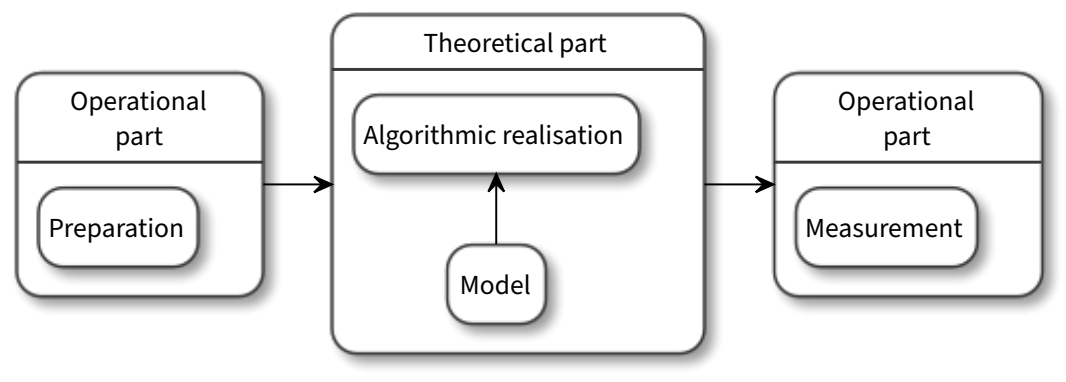

Figure 4. Generic structure of the simulation model

\section{PHYSICAL MODEL}

The resulting mathematical model should be compared with experimental data and verified. Unfortunately, we do not have the resources to take data from a working network or build a full-scale test bench on real network equipment. Therefore, we tried to create a virtual experimental installation based on the virtual machines [11]. Virtual machines run images of real routers operating systems. This is what allows us to call this model physical.

To create the stand, the software package GNS3 (Graphical Network Simulator) [12] was chosen. This allows you to simulate a virtual network of routers and virtual machines. The software package GNS3 works on almost all platforms. It can be considered as a graphical interface for different virtual machines. To emulate Cisco devices the Dynamips emulator is used. Alternatively, emulators such as VirtualBox and Qemu can be used. The latter is especially useful when it used with a KVM system which allows a hardware processor implementation. GNS3 coordinates the operation of various virtual machines and also provides the researcher with a convenient interface for creation and customization of the required stand configuration. Also, the developed topology can be linked to an external network to manage and control data packets.

The stand consists of a Cisco router, a traffic generator, and a receiver. D-ITG (Distributed Internet Traffic Generator) is used as a traffic generator (see Fig. 3). D-ITG allows us to obtain estimates of the main indicators of the quality of service (average packet transmission delay, delay variation (jitter), packet loss rate, performance) with a high degree of confidence.

\section{SIMULATION MODEL}

With the development of computer technology it became possible to specify a model implementation not in the form of a mathematical description, but in the form of some algorithm (Fig. 4). This type of model is called simulation models and the approach itself is called simulation.

The simulation model plays a dual role. The simulation model, debugged and tested on experimental data and a 


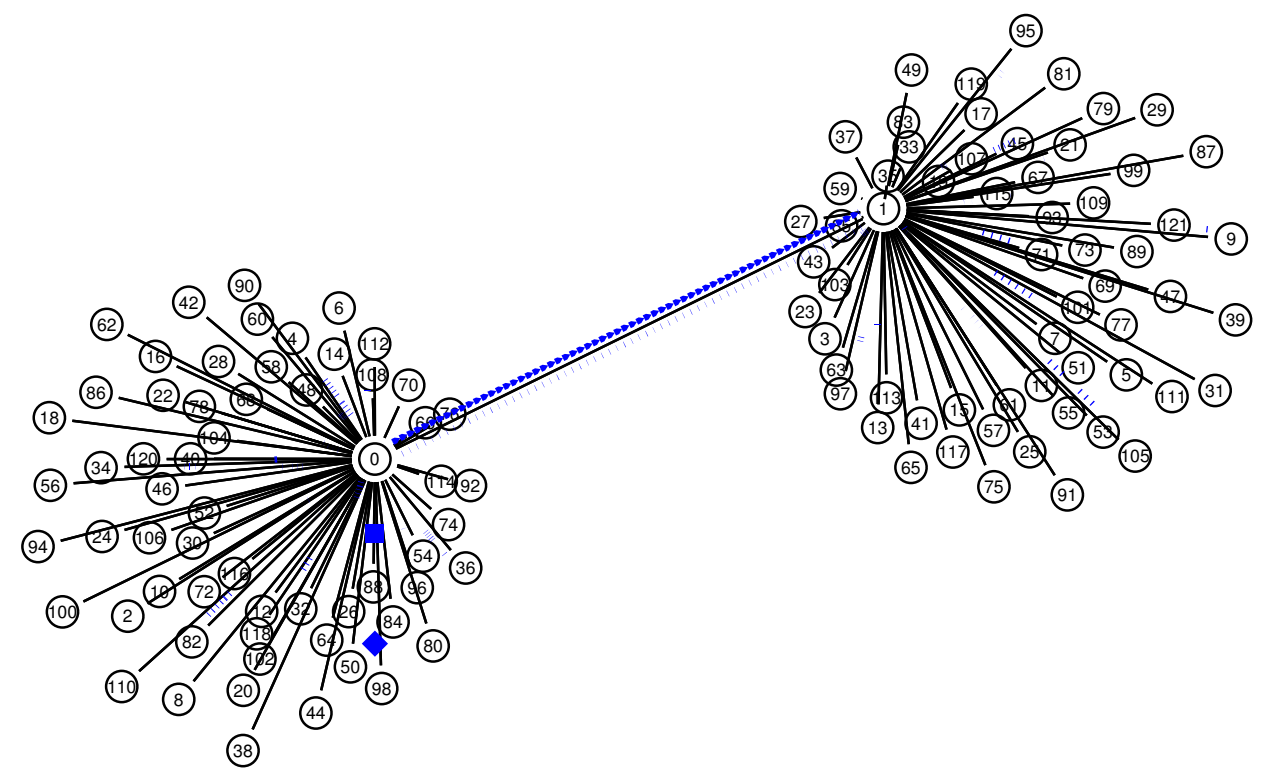

Figure 5. Visualization of the simulation. Packets drop is shown

physical model, can itself serve the purposes of the mathematical model verification. On the other hand, the simulation model makes it possible to study the behavior of the modeled system more effectively than the mathematical model for different variants of the input data.

\section{A. Simulation model on NS-2}

The ns2 $[13,14]$ package is the network protocol simulation tool. During its existence, the functionality has been repeatedly verified by data from field experiments. Therefore, this package itself has become a reference modeling tool. This is exactly the case when a simulation model is a replacement for a physical model and a natural experiment.

The program for ns2 is written in the TCL language $[15,16]$. The simulation results can be represented using visualization tool nam (see Fig. 5).

The simulator is built on an event-driven architecture. That is, it implements a discrete approach to modeling. On the one hand, this is a plus, since it directly implements the TCP and RED specification (see section III). On the other hand, the amount of resulting data sharply increases, which makes it difficult to carry out any lengthy simulation experiment.

In our works, this software is used precisely for verification of the obtained results $[17,18]$.

\section{B. Hybrid model for RED algorithm}

To study the RED algorithm we developed the prototype of the simulation model. We wanted to avoid the resource intensiveness of discrete modeling approaches. However, it was necessary to take into account the discrete specifics of TCP and RED (see section III). Therefore, we have chosen a hybrid (continuous-discrete) approach. The model was implemented in the hybrid modeling language Modelica [19, 20].

Since we are building the hybrid continuous-discrete model, then to describe each phase of TCP functioning, we will turn to the model with continuous time. The transition between phases will be described by discrete states.

To build a hybrid model, we need:

- write a dynamic model for each state;

- replace systems with piecewise constant parameters with systems with variable initial conditions;

- write the state diagram of the model (Fig. 6 and 7).

The resulting diagrams are directly converted into a Modelica program [21-23]. 


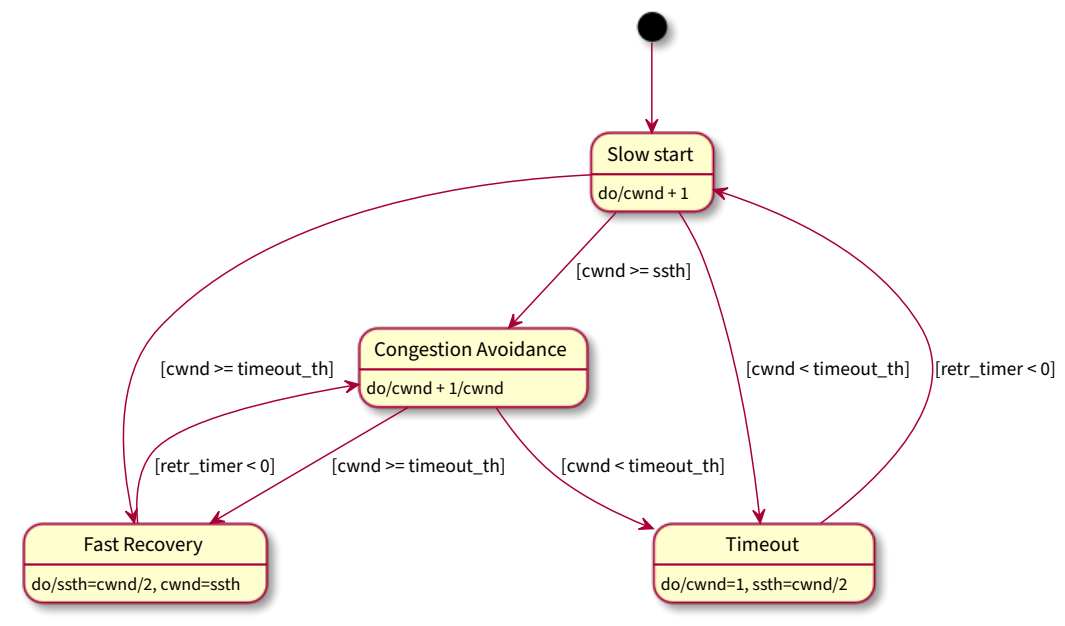

Figure 6. TCP state diagram

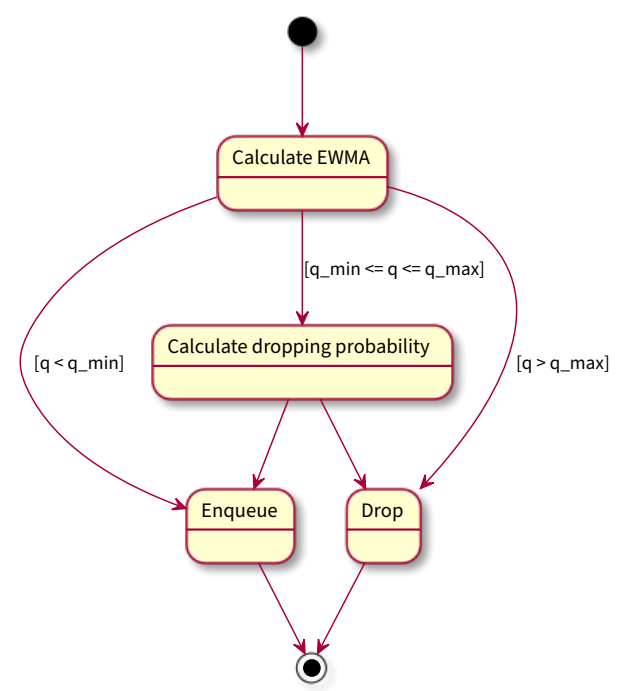

Figure 7. RED state diagram

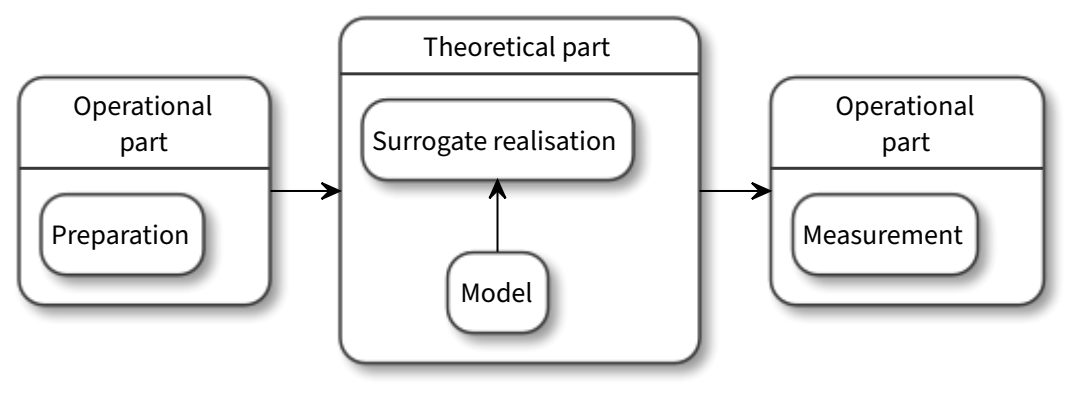

Figure 8. Generic structure of the surrogate model

\section{SURROGATE MODEL}

Most scientific and technical problems require experiments and simulations to obtain results, to determine the limitations imposed on the result. However, for many real-world problems simulation alone can take minutes, hours, days. As a result, routine tasks such as decision optimization, decision space exploration, sensitivity analysis, and what-if analysis become impossible as they require thousands or millions of modeling evaluations.

One way to simplify research is to build surrogate models (approximation models, response surface models, metamodels, black box models) (see Fig. 8) that mimic the behavior of the original model so closely as much as possible, while being computationally cheap [24]. Surrogate models are built using a data-driven approach. The exact inner workings of the simulation code are not supposed to be known (or even understood), only the input-output (preparation-measurement) behavior is important. The model is built based on modeling the response to a limited number (sometimes quite large) of selected data points ${ }^{1}$.

The scientific challenge for surrogate modeling is to create a surrogate that is as accurate as possible using as few modeling estimates as possible. The process consists of the following main stages [25]:

- sample selection;

- construction of the surrogate model and optimization of model parameters;

- an estimate of the accuracy of the surrogate.

\footnotetext{
${ }^{1}$ Note that this type of model is known to many researchers. When only one modeling variable is involved, the process of building the surrogate model is called curve fitting
} 
For some problems the nature of the true function is a priori unknown, so it is unclear which surrogate model will be the most accurate. Moreover, it is not clear how to obtain the most reliable estimates of the accuracy of a given surrogate. In this case, the model layer (Fig. 8) is replaced by the researcher's guess. In our case, the surrogate model is based on a clearly formulated mathematical model, which allows us to obtain clear, substantiated results of surrogate modeling.

At this moment we are developing a methodology for constructing surrogate models for both RED type algorithms and arbitrary stochastic one-step processes.

\section{CONCLUSION}

The authors tried to outline the concept of a multi-model approach to the study of physical and technical systems using the example of the interaction between the TCP protocol and the RED-type active queue management algorithm. This research is in line with the research of stochastic models in science and technology.

The multi-model approach makes it possible to increase the efficiency of the study of the phenomenon, to consider it from different angles, and to create effective software systems.

\section{ACKNOWLEDGMENTS}

The publication has been prepared with the support of the "RUDN University Program 5-100" and funded by Russian Foundation for Basic Research (RFBR) according to the research project No 19-01-00645.

[1] S. Floyd, V. Jacobson, Random Early Detection Gateways for Congestion Avoidance, IEEE/ACM Transactions on Networking 1 (4) (1993) 397-413. doi:10.1109/90.251892.

[2] V. Misra, W.-B. Gong, D. Towsley, Stochastic Differential Equation Modeling and Analysis of TCP-Windowsize Behavior, Proceedings of PERFORMANCE 99 (1999).

[3] V. Misra, W.-B. Gong, D. Towsley, Fluid-Based Analysis of a Network of AQM Routers Supporting TCP Flows with an Application to RED, ACM SIGCOMM Computer Communication Review 30 (4) (2000) 151-160. doi:10.1145/347057. 347421.

[4] C. V. V. Hollot, V. Misra, D. Towsley, A Control Theoretic Analysis of RED, in: Proceedings IEEE INFOCOM 2001. Conference on Computer Communications. Twentieth Annual Joint Conference of the IEEE Computer and Communications Society (Cat. No.01CH37213), Vol. 3, IEEE, 2001, pp. 1510-1519. doi:10.1109/INFCOM.2001.916647.

[5] M. N. Gevorkyan, A. V. Demidova, T. R. Velieva, A. V. Korol'kova, D. S. Kulyabov, L. A. Sevast'yanov, Implementing a Method for Stochastization of One-Step Processes in a Computer Algebra System, Programming and Computer Software 44 (2) (2018) 86-93. arXiv:1805.03190, doi:10.1134/S0361768818020044.

[6] M. Hnatič, E. G. Eferina, A. V. Korolkova, D. S. Kulyabov, L. A. Sevastyanov, Operator Approach to the Master Equation for the One-Step Process, EPJ Web of Conferences 108 (2016) 02027. arXiv:1603.02205, doi:10.1051/epjconf/201610802027.

[7] A. V. Korolkova, E. G. Eferina, E. B. Laneev, I. A. Gudkova, L. A. Sevastianov, D. S. Kulyabov, Stochastization Of One-Step Processes In The Occupations Number Representation, Proceedings 30th European Conference on Modelling and Simulation (2016) 698-704doi:10.7148/2016-0698.

[8] A. V. Korolkova, D. S. Kulyabov, T. R. Velieva, I. S. Zaryadov, Essay on the study of the self-oscillating regime in the control system, in: M. Iacono, F. Palmieri, M. Gribaudo, M. Ficco (Eds.), 33 European Conference on Modelling and Simulation, ECMS 2019, Vol. 33 of Communications of the ECMS, European Council for Modelling and Simulation, Caserta, 2019, pp. 473-480. doi:10.7148/2019-0473.

[9] T. R. Velieva, D. S. Kulyabov, A. V. Korolkova, I. S. Zaryadov, The approach to investigation of the the regions of self-oscillations, Journal of Physics: Conference Series 937 (2017) 012057.1-8. doi:10.1088/1742-6596/937/1/012057.

[10] T. R. Velieva, A. V. Korolkova, D. S. Kulyabov, B. A. Dos Santos, Model Queue Management on Routers, Bulletin of Peoples' Friendship University of Russia. Series "Mathematics. Information Sciences. Physics" 2 (2014) 81-92.

[11] T. R. Velieva, A. V. Korolkova, D. S. Kulyabov, Designing Installations for Verification of the Model of Active Queue Management Discipline RED in the GNS3, in: 6th International Congress on Ultra Modern Telecommunications and Control Systems and Workshops (ICUMT), IEEE Computer Society, 2015, pp. 570-577. arXiv:1504.02324, doi:10.1109/ ICUMT . 2014.7002164.

[12] C. Welsh, GNS3 network simulation guide, PACKT Publisher, 2013.

[13] T. Issariyakul, E. Hossain, Introduction to Network Simulator NS2, Springer US, Boston, MA, 2012. doi:10.1007/ 978-1-4614-1406-3.

[14] E. Altman, T. Jiménez, NS Simulator for Beginners, Synthesis Lectures on Communication Networks 5 (1) (2012) 1-184. doi:10.2200/S00397ED1V01Y201112CNT010. 
[15] B. Welch, K. Jones, Practical Programming in Tcl and Tk, 4th Edition, Prentice Hall, 2003.

[16] A. P. Nadkarni, The Tcl Programming Language: A Comprehensive Guide, CreateSpace Independent Publishing Platform, 2017.

[17] T. R. Velieva, A. V. Korolkova, D. S. Kulyabov, S. A. Abramov, Parametric study of the control system in the TCP network, in: 10th International Congress on Ultra Modern Telecommunications and Control Systems, Moscow, 2019, pp. 334-339. doi:10.1109/ICUMT.2018.8631267.

[18] T. R. Velieva, A. V. Korolkova, A. V. Demidova, D. S. Kulyabov, Software Package Development for the Active Traffic Management Module Self-oscillation Regime Investigation, in: W. Zamojski, J. Mazurkiewicz, J. Sugier, T. Walkowiak, J. Kacprzyk (Eds.), Contemporary Complex Systems and Their Dependability: Proceedings of the Thirteenth International Conference on Dependability and Complex Systems DepCoS-RELCOMEX, July 2-6, 2018, Brunów, Poland, Vol. 761 of Advances in Intelligent Systems and Computing, Springer International Publishing, Cham, 2019, conference paper 48, pp. 515-525. doi:10.1007/978-3-319-91446-6_48.

[19] P. Fritzson, Principles of Object-Oriented Modeling and Simulation with Modelica 2.1, Wiley-IEEE Press, 2003.

[20] P. Fritzson, Introduction to Modeling and Simulation of Technical and Physical Systems with Modelica, John Wiley \& Sons, Inc., Hoboken, NJ, USA, 2011. doi:10.1002/9781118094259.

[21] T. R. Velieva, E. G. Eferina, A. V. Korolkova, D. S. Kulyabov, L. A. Sevastianov, Modelica-based TCP simulation, Journal of Physics: Conference Series 788 (100) (2017) 012036.1-7. doi:10.1088/1742-6596/788/1/012036.

[22] A.-M. Y. Apreutesey, A. V. Korolkova, D. S. Kulyabov, Modeling RED algorithm modifications in the OpenModelica, in: D. S. Kulyabov, K. E. Samouylov, L. A. Sevastianov (Eds.), Proceedings of the Selected Papers of the 9th International Conference "Information and Telecommunication Technologies and Mathematical Modeling of High-Tech Systems" (ITTMM-2019), Moscow, Russia, April 15-19, 2019, Vol. 2407 of CEUR Workshop Proceedings, Moscow, 2019, pp. 5-14.

[23] A. V. Korolkova, T. R. Velieva, P. A. Abaev, L. A. Sevastianov, D. S. Kulyabov, Hybrid Simulation Of Active Traffic Management, Proceedings 30th European Conference on Modelling and Simulation (2016) 685-691doi:10.7148/2016-0685.

[24] Y. Jin, Surrogate-assisted evolutionary computation: Recent advances and future challenges, Swarm and Evolutionary Computation 1 (2) (2011) 61-70. doi:10.1016/j.swevo.2011.05.001.

[25] L. A. Sevastianov, A. L. Sevastianov, E. A. Ayrjan, A. V. Korolkova, D. S. Kulyabov, I. Pokorny, Structural Approach to the Deep Learning Method, in: V. Korenkov, T. Strizh, A. Nechaevskiy, T. Zaikina (Eds.), Proceedings of the 27th Symposium on Nuclear Electronics and Computing (NEC-2019), Vol. 2507 of CEUR Workshop Proceedings, Budva, 2019, pp. 272-275. 


\title{
Практическое применение мультимодельного подхода при исследовании сложных систем
}

\author{
А. В. Королькова, ${ }^{1, *}$ Д. С. Кулябов, ${ }^{1,2, \dagger}$ и М. Гнатич ${ }^{3, \ddagger}$ \\ ${ }^{1}$ Кафедра прикладной информатики и теории вероятностей, \\ Российский университет дружбы народов, \\ 117198, Москва, ул. Миклухо-Маклал, д. 6 \\ 2 Лаборатория информачионных технологий, \\ Объединённый институт ядерных исследований, \\ ул. Жолио-Кюри 6, Дубна, Московская область, Россия, 141980 \\ ${ }^{3}$ Лаборатория теоретической физики, \\ Объединённый институт ядерных исследований, \\ ул. Жолио-Кюри 6, Дубна, Московская область, Россия, 141980
}

\begin{abstract}
Для исследования разнообразных природных и технических явлений используется разные типы моделей. Обычно исследователь ограничивается использованием какого-то определённого типа модельного подхода, не используя другие (или даже не осознавая существование других модельных подходов). Авторы считают, что полное исследование некоторого явления должно охватывать несколько модельных подходов. В работе описываются несколько модельных подходов, использованные нами при исследовании модуля активного управления трафиком RED. Описываются как сами модельные подходы, так и их реализации и полученные результаты.

Ключевыеслова: активное управление трафиком, математическое моделирование, имитационное моделирование, суррогатное моделирование, стохастические системы
\end{abstract}

\footnotetext{
* korolkova-av@rudn.ru

† kulyabov-ds@rudn.ru

¥ hnatic@saske.sk
} 


\section{I. ВВЕДЕНИЕ}

Научное исследование легко начать, но трудно завершить. Наше исследование алгоритма RED выделилось из исследования подходов и механизмов управления трафиком в сетях передачи данных. Но чем дальше мы продвигались, тем менее нас удовлетворяли полученные результаты. Первоначально построенная математическая модель казалась нам несколько искусственной и нерасширяемой. Для построения более естественной математической модели из первых принципов нами была разработана методика стохастизации одношаговых процессов. Для верификации математической модели нами были построены физическая и имитационные модели. Для проведения оптимизационных исследований мы стали строить суррогатную модель алгоритма RED. B конце концов мы достигли понимания, что все наши модели образуют некоторую эмерджентную структуру, с помощью которой можно исследовать разнообразные явления. В частности, стохастические и статистические системы.

В этой работе мы пытаемся представить наше понимание мультимодельного подхода к моделированию.

\section{II. МОДЕЛЬНЫЕ ПОДХОДЫ}

Моделирование как дисциплина охватывает разные типы модельных подходов. С нашей точки зрения эти подходы можно схематически описать единым образом (см. рис. 1). В данном случае структура исследования состоит из операциональных и теоретических частей. Операциональные части представлены процедурами приготовления системы и измерения. Также распространено описание операциональной части как входных и выходных данных.

Теоретическая часть состоит из двух слоёв: модельного слоя и слоя реализации. Слой реализации описывает конкретную структуру эволюции системы. В зависимости от типа реализации, можно получать разные виды моделей: математическую модель (реализация - математические выражения), имитационная модель (реализация - алгоритм), физическая модель (реализация - аналоговая система), суррогатная модель (реализация аппроксимация поведения). Каждый тип моделей имеет свою область применимости, свои преимущества и недостатки. Использование всего спектра моделей позволяет наиболее глубокое и всестороннее исследование моделируемой системы.

\section{III. АЛГОРИТМ АКТИВНОГО УПРАВЛЕНИЯ ТРАФИКОМ RЕD}

Алгоритм Random Early Detection (RED) лежит в основе ряда механизмов предотвращения и контроля перегрузок в очередях маршрутизаторов. Его основное предназначение заключается в сглаживании временных всплесков трафика и предупреждении длительной перегрузки сети посредством уведомления источников трафика о необходимости снижения интенсивности передачи информации.

Функционирование модуля, реализующего алгоритм типа RED, можно схематично представить следующим образом.

Пакет передаваемых данных при поступлении в систему попадает в модуль сброса. Решение о сбросе пакета принимается на основе значения функции $p(\hat{q})$, получаемого от управляющего модуля. Функция $p(\hat{q})$ зависит от значения экспоненциально взвешенного скользящего среднего размера длины очереди $\hat{q}$, также вычисляемого управляющим модулем, основываясь на текущем значении длины очереди $q$.

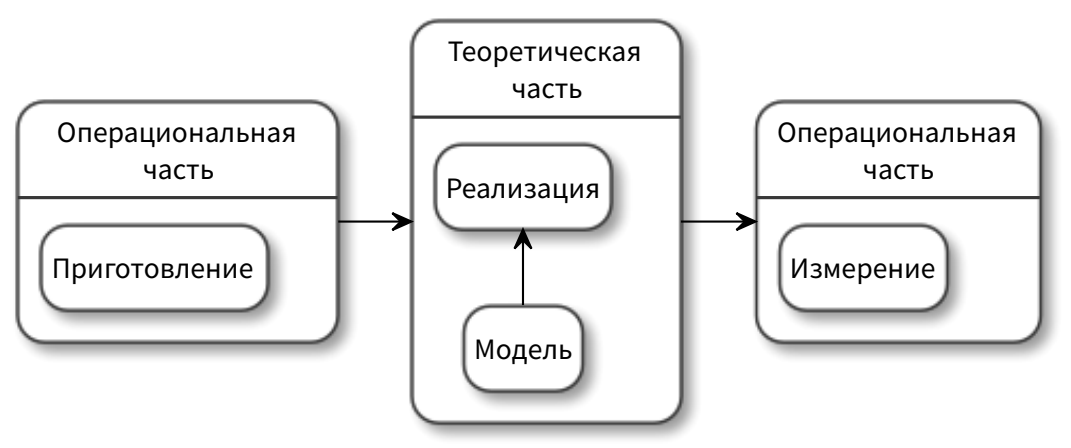

Рис. 1. Общая структура модельного подхода 
Классический алгоритм RED подробно рассмотрен в работе [1]. Здесь приведены лишь формулы для расчёта функции сброса $p(\hat{q})$ и экспоненциально взвешенной скользящей средней длины очереди $\hat{q}$. Использование $\hat{q}$ вызвано необходимостью сглаживания выбросов мгновенной длины очереди $q$.

Для вычисления $\hat{q}$ используется рекуррентная формула экспоненциально взвешенного скользящего среднего (Exponentially Weighted Moving-Average, EWMA):

$$
\hat{q}_{k+1}=\left(1-w_{q}\right) \hat{q}_{k}+w_{q} q_{k}, \quad k=0,1,2, \ldots,
$$

где $w_{q}, 0<w_{q}<1-$ весовой коэффициент экспоненциально взвешенного скользящего среднего:

$$
w_{q}=1-e^{-1 / C}
$$

где $C$ - пропускная способность канала (пакетов в секунду).

Функция $p(\hat{q})$ сброса пакетов линейно зависит от $\hat{q}$, минимального $q_{\min }$ и максимального $q_{\text {max }}$ пороговых значений и параметра максимального сброса $p_{\max }$, задающего максимальный уровень сброса пакетов при достижении $\hat{q}$ значения $q_{\max }$, и вычисляется следующим образом:

$$
p(\hat{q})= \begin{cases}0, & 0<\hat{q} \leqslant q_{\min }, \\ \frac{\hat{q}-q_{\min }}{q_{\max }-q_{\min }} p_{\max }, & q_{\min }<\hat{q} \leqslant q_{\max }, \\ 1, & \hat{q}>q_{\max } .\end{cases}
$$

Данная функция сброса (1) описывает классический алгоритм RED. И основные усилия при конструировании новых алгоритмов типа RED направлено на разные модификации вида функции сброса.

Поскольку полная моделируемая система состоит из взаимодействующих протокола TCP и алгоритма RED, то необходимо моделировать также и эволюцию источника, работающего по протоколу ТСР. Поскольку оригинальная модель базировалась на протоколе TCP Reno, то нами моделировался именно этот протокол.

В протоколе ТСР используется механизм скользящего окна для борьбы с перегрузками. Реализация данного механизма зависит от конкретного стандарта протокола ТСР.

B TCP Reno механизм управления перегрузками состоит из следующих фаз: медленный старт, предотвращение перегрузок, быстрая передача и быстрое восстановление. Динамика изменения размера окна перегрузки (Congestion Window, CWND) зависит от конкретной фазы.

Протокол TCP Reno отслеживает два варианта потери пакетов:

- Тройное дублирование подтверждения (Triple Duplicate ACK, TD). Пусть $n$-й пакет не доставлен, а последующие пакеты $(n+1, n+2$ и т.д.) доставлены. Для каждого пакета, доставленного в нарушении очерёдности (для $n+1, n+2$ и т.д.) получатель отсылает сообщение АCK для последнего недоставленного $(n$-го) пакета. При получении трёх таких пакетов источник перепосылает $n$-й пакет. Кроме того, размер окна уменьшается в 2 раза $c w n d \rightarrow c w n d / 2$.

- Тайм-аут (Timeout, TO). При отправке пакета запускается таймер тайм-аута. При получении каждого подтверждения таймер перезапускается. Окно при этом устанавливается в начальное значение окна перегрузки. Первый потерянный пакет перепосылается. Протокол переходит в фазу медленного старта.

Общий алгоритм управления перегрузкой относится к типу AIMD (Additive Increase, Multiplicative Decrease) аддитивное увеличение размера окна и мультипликативное его уменьшение.

\section{IV. МАТЕМАТИЧЕСКАЯ МОДЕЛЬ}

Наиболее строгое исследование базируется, обычно, на математической модели (см. рис. 2). В этом случае модельный слой реализуется посредством математических выражений, описывающих эволюцию системы.

Есть несколько подходов к моделированию алгоритмов типа RED. Наиболее известным подходом является моделирование с использование подхода теории автоматического управления [2-4]. Нам этот подход представляется несколько искусственным и непоследовательным. Мы предпочитаем проводить моделирование из первых принципов.

Нами разработан метод стохастизации одношаговых процессов, который позволяет получать модели из первых принципов. При этом полученные модели модели являются имманентно стохастическими [5-7]. Наша модель взаимодействия источника TCP и алгоритма RED строится на основе этих методов и математически представляется в виде стохастических дифференциальных уравнений с винеровским и пуассоновским процессом [8-10]. 


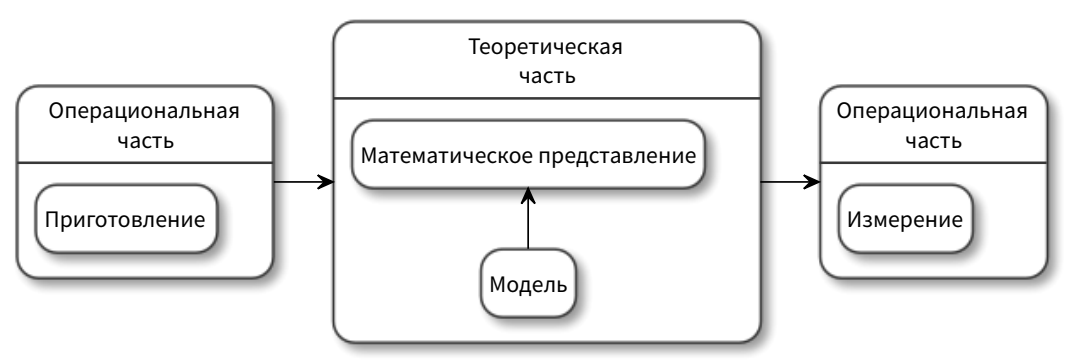

Рис. 2. Общая структура математической модели

Будем использовать следующие обозначения. $W(t)$ - функция изменения размера окна TCP Reno, $Q(t)-$ функция изменения размера очереди, $T:=T(Q(t))$ - время двойного оборота с учётом задержек обработки пакетов в оборудовании, $t-$ время, $C$ - интенсивность обслуживания пакетов в очереди, $\hat{Q}(t)-$ функция экспоненциально взвешенного скользящего среднего (Exponentially Weighted Moving-Average, EWMA) [1]:

$$
\hat{Q}(t)=\left(1-w_{q}\right) \hat{Q}(t)+w_{q} Q(t),
$$

где $w_{q}, 0<w_{q}<1-$ весовой коэффициент.

Мы использовали метод стохастизации одношаговых процессов для получения уравнений Фоккера-Планка и Ланжевена для случайных процессов $W(t)$ и $Q(t)$.

Кинетические уравнения будут иметь вид:

$$
\left\{\begin{array}{l}
0 \stackrel{\frac{1}{W(t)}}{\longrightarrow} W(t), \\
W(t) \stackrel{\frac{1}{2} \frac{\mathrm{d} N(t)}{\mathrm{d} t}}{\longrightarrow} 0, \\
0 \stackrel{\frac{W(t)}{T}}{\longrightarrow} Q(t), \\
0 \stackrel{-C}{\longrightarrow} Q(t),
\end{array}\right.
$$

где $\mathrm{d} N(t)$ - пуассоновский процесс [3].

Выпишем уравнения Фоккера-Планка, соответствующее кинетическим уравнениям (2):

$$
\begin{gathered}
\frac{\partial w(t)}{\partial t}=-\frac{\partial}{\partial W(t)}\left[\left(\frac{1}{W(t)}-\frac{W(t)}{2} \frac{\mathrm{d} N(t)}{\mathrm{d} t}\right) w(t)\right]+ \\
+\frac{1}{2} \frac{\partial^{2}}{\partial W^{2}(t)}\left[\left(\frac{1}{W(t)}+\frac{W(t)}{2} \frac{\mathrm{d} N(t)}{\mathrm{d} t}\right) w(t)\right], \\
\frac{\partial q(t)}{\partial t}=-\frac{\partial}{\partial Q(t)}\left[\left(\frac{W(t)}{T}-C\right) q(t)\right]+ \\
+\frac{1}{2} \frac{\partial^{2}}{\partial Q^{2}(t)}\left[\left(\frac{W(t)}{T}-C\right) q(t)\right],
\end{gathered}
$$

где $w(t)$ - плотность распределения случайного процесса $W(t), q(t)$ - плотность распределения случайного процесса $Q(t)$.

Соответствующие уравнениям (3) уравнения Ланжевена имеет вид:

$$
\left\{\begin{array}{l}
\mathrm{d} W(t)=\frac{1}{T} \mathrm{~d} t-\frac{W(t)}{2} \mathrm{~d} N(t)+\sqrt{\frac{1}{T}+\frac{W(t)}{2} \frac{\mathrm{d} N(t)}{\mathrm{d} t}} \mathrm{~d} V^{1}(t), \\
\mathrm{d} Q(t)=\left(\frac{W(t)}{T}-C\right) \mathrm{d} Q(t)+\sqrt{\frac{W(t)}{T}-C} \mathrm{~d} V^{2}(t),
\end{array}\right.
$$

где $\mathrm{d} V^{1}(t)$ - винеровский процесс, соответствующий случайному процессу $W(t), \mathrm{d} V^{2}(t)$ - винеровский процесс, соответствующий случайному процессу $Q(t)$. 


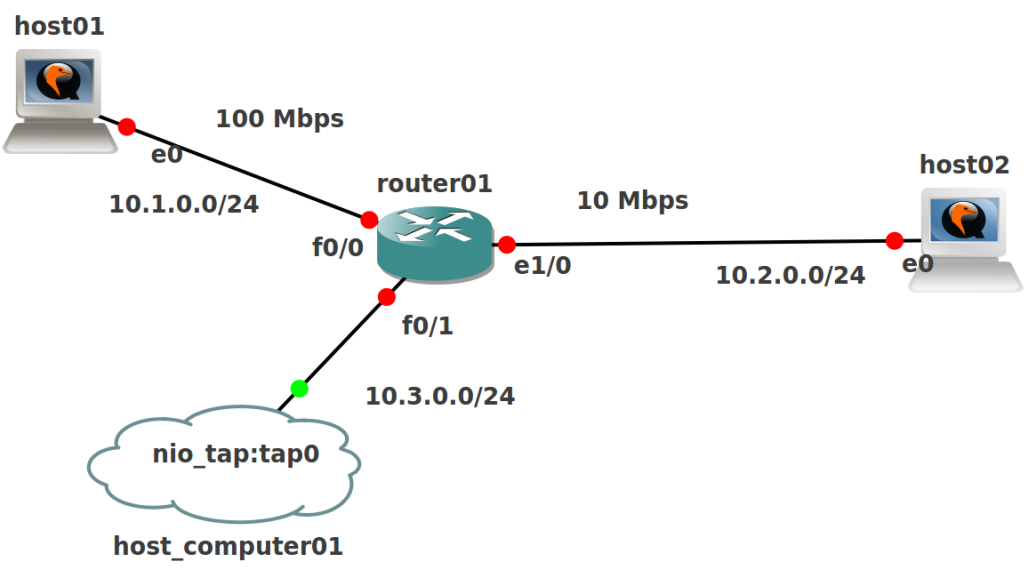

Рис. 3. Виртуальный стенд для исследования функционирования алгоритма RED. host01 - источник пакетов; host02 получатель.

Уравнения (4) дополняются уравнением связи (для удобства записанное в дифференциальном виде):

$$
\frac{\mathrm{d} \hat{Q}(t)}{\mathrm{d} t}=w_{q} C(Q(t)-\hat{Q}(t))
$$

Исследовать данную математическую модель можно как в виде стохастических дифференциальных уравнений, так и записав их в моментах. Уравнение в моментах, естественно, легче для исследования.

\section{V. ФИЗИЧЕСКАЯ МОДЕЛЬ}

Полученную математическую модель нужно сопоставить с экспериментальными данными, верифицировать её. $\mathrm{K}$ сожалению, мы не обладаем ресурсами для снятия показаний с работающей сети или для построения натурного стенда на настоящем сетевом оборудовании. Поэтому нами была произведена попутка собрать виртуальную экспериментальную установку на основе виртуальных машин [11]. На виртуальных машинах выполняются образы операционных систем реальных маршрутизаторов. Именно это позволяет нам называть данную модель физической.

Для построения стенда был выбран программный комплекс GNS3 (Graphical Network Simulator) [12]. Он позволяет моделировать виртуальную сеть из маршрутизаторов и виртуальных машин. Работает практически на всех платформах. Фактически это графический интерфейс для разных виртуальных машин. Для эмуляции устройств Cisco используется эмулятор dynamips. Кроме того, можно использовать такие эмуляторы, как VirtualBox и Qemu. Последний особенно удобен при использовании с системой KVM, позволяющей использовать аппаратную реализацию процессора. Фактически, GNS3 осуществляет оркестрацию работы разных виртуальных машин, а также предоставляет исследователю удобный интерфейс создания и настройки необходимой конфигурации стенда. Кроме того, есть возможность соединения проектируемой топологии с внешней сетью для управления и манипуляций пакетами данных.

Стенд состоит из маршрутизатора Cisco, генератора трафика и получателя. В качестве генератора трафика используется D-ITG (Distributed Internet Traffic Generator) (рис. 3). D-ITG позволяет получить оценки основных показателей качества обслуживания (средняя задержка передачи пакетов, вариация задержки (джиттер), коэффициент потерь пакетов, производительность) с высокой степенью достоверности.

\section{VI. ИМИТАЦИОННАЯ МОДЕЛЬ}

С развитием компьютерной техники появилась возможность задавать модельную реализацию не в виде математического описания, а в виде некоторого алгоритма (рис. 4). Такого типа модели получили название имитационных моделей, а сам подход получил название имитационного моделирования.

Имитационная модель играет двоякую роль. Отлаженная и проверенная на экспериментальных данных и физической модели имитационная модель сама по себе может служить целям верификации математической 


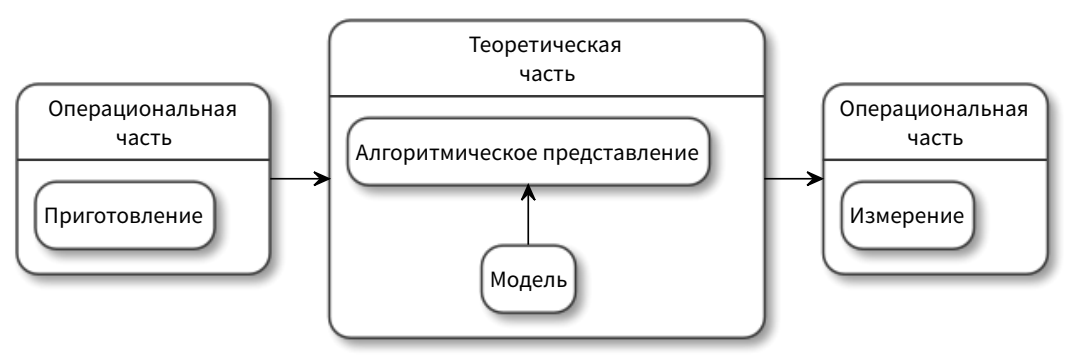

Рис. 4. Общая структура имитационной модели

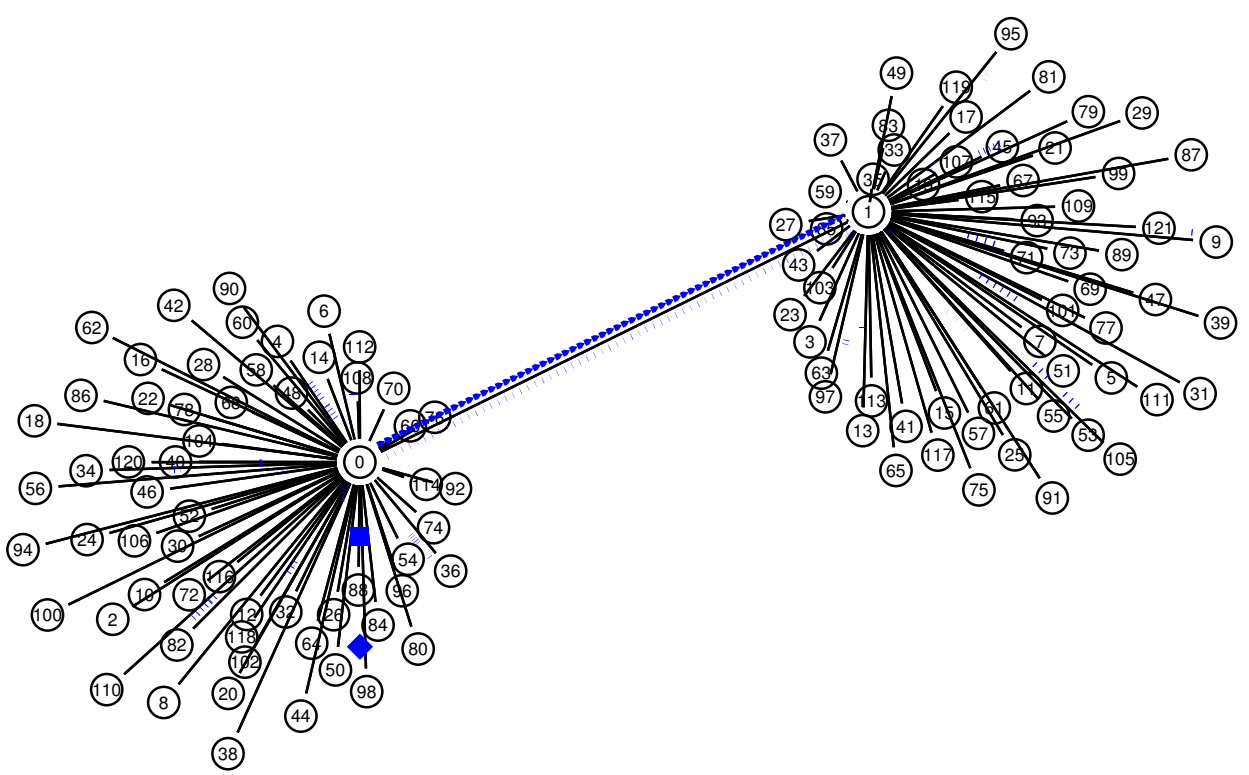

Рис. 5. Визуализация моделирования системы. Показан сброс пакетов

модели. С другой стороны, имитационная модель позволяет более эффективно, чем математическая модель, исследовать поведение моделируемой системы при разных вариантах входных данных.

\section{А. Имитационная модель на NS-2}

Пакет ns2 $[13,14]$ является средством имитационного моделирования сетевых протоколов. За время своего существования функционал многократно верифицировался данными натурных экспериментов. Поэтому этот пакет сам стал эталонном средством моделирования. Это именно тот случай, когда имитационная модель является заменой физической модели и натурного эксперимента.

Программа для ns2 пишется на языке TCL $[15,16]$. Результаты моделирования можно представить с помощью средства визуализации nam (см. рис. 5).

Средство моделирования построено по событийно-ориентированной архитектуре. То есть реализует дискретный подход к моделирования. С одной стороны это является плюсом, поскольку напрямую реализует спецификацию TCP и RED (см. раздел III). С другой стороны резко возрастает количество результирующих данных, что делает затруднённым проведение сколь-либо длительного имитационного эксперимента.

В наших работах данный программный продукт используется именно как средство верификации полученных результатов $[17,18]$. 


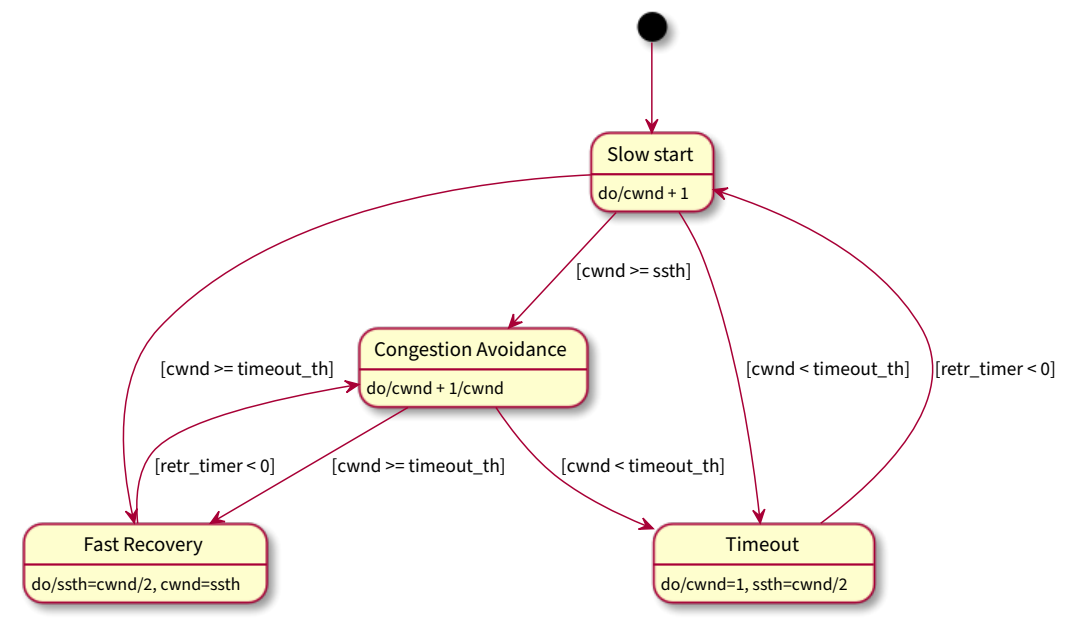

Рис. 6. Диаграмма состояний ТСР

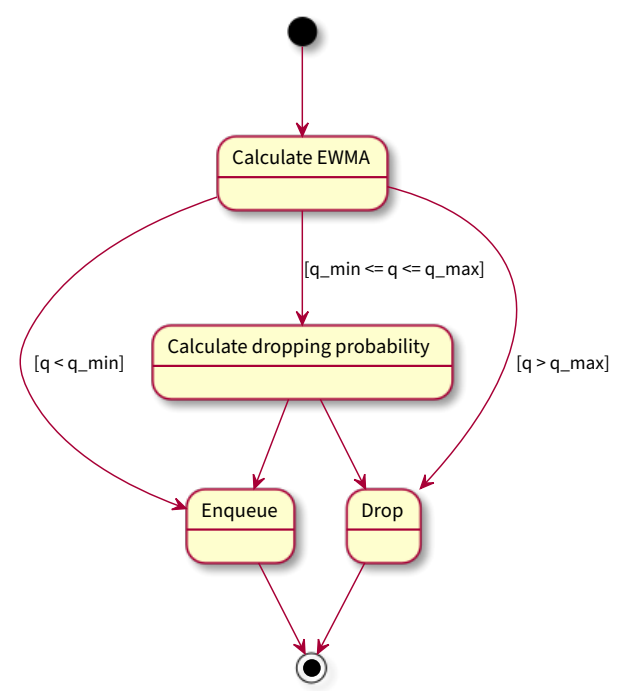

Рис. 7. Диаграмма состояний RED

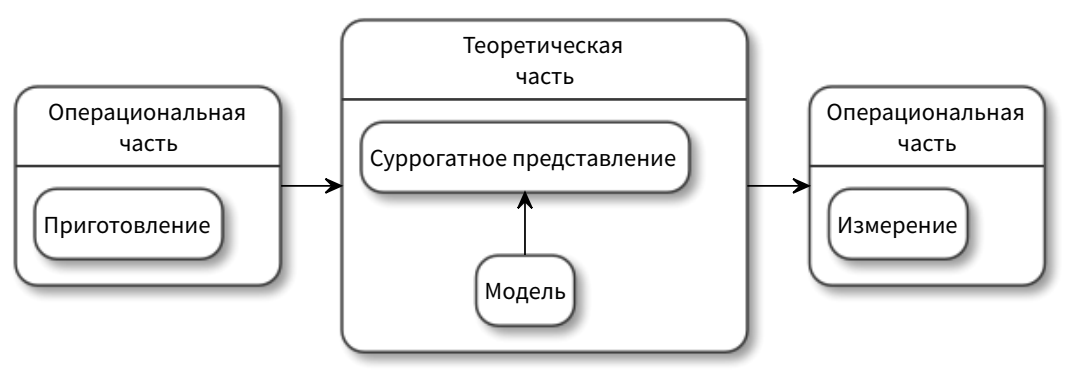

Рис. 8. Общая структура суррогатной модели

\section{B. Гибридная модель алгоритма RED}

Для исследования алгоритма RED нами был разработан прототип имитационной модели. Мы хотели избежать ресурсозатратности дискретных подходов моделирования. Но при этом необходимо было учесть дискретную спецификацию TCP и RED (см. раздел III). Поэтому нами был выбран гибридный (непрерывно-дискретный) подход. Модель была реализована на языке гибридного моделирования Modelica [19, 20].

Поскольку мы строим гибридную непрерывно-дискретную модель, то для описания каждой фазы функционирования ТСР перейдём к модели с непрерывным временем. Переход же между фазами будет описываться дискретными состояниями.

Для построения гибридной модели необходимо:

• записать динамическую модель для каждого состояния;

• заменить системы с кусочно-постоянными параметрами на системы с переменными начальными условиями;

- записать диаграмму состояний модели (рис. 6 и 7).

Полученные диаграммы непосредственно преобразовываются в программу на языке Modelica [21-23].

\section{VII. СУРРОГАТНАЯ МОДЕЛЬ}

Большинство научных и технических проблем требуют экспериментов и моделирования для получения результатов, определения ограничений, накладываемых на результат. Однако для многих реальных проблем одно только моделирование может занять несколько минут, часов, дней. В результате рутинные задачи, такие 
как оптимизация решений, исследование пространства решений, анализ чувствительности и анализ «что, если» становятся невозможными, поскольку они требуют тысяч или миллионов оценок моделирования.

Один из способов упростить исследование - построить суррогатные модели (аппроксимационные модели, модели поверхности отклика, метамодели, модели чёрного ящика) (см. рис. 8), которые имитируют поведение исходной модели настолько близко, насколько это возможно, в то время как вычислительно дёшевы [24]. Суррогатные модели строятся с использованием подхода, основанного на данных. Точная внутренняя работа кода моделирования не предполагается известной (или даже понятой), важно только поведение ввода-вывода (приготовления-измерения). Модель строится на основе моделирования реакции на ограниченное количество (порой достаточно большое) выбранных точек данных ${ }^{1}$.

Научная задача суррогатного моделирования заключается в создании суррогата, который является максимально точным, используя как можно меньше оценок моделирования. Процесс состоит из следующих основных этапов, которые могут чередоваться [25]:

- выбор образца;

• построение суррогатной модели и оптимизация параметров модели;

- оценка точности суррогата.

Для некоторых проблем природа истинной функции априори неизвестна, поэтому неясно, какая суррогатная модель будет наиболее точной. Кроме того, непонятно, как получить наиболее надёжные оценки точности данного суррогата. В данном случае модельный слой (рис. 8) заменяется догадками исследователя. В нашем же случае суррогатная модель базируется на ясно сформулированной математической модели, что позволяет получить ясные, обоснованные результаты суррогатного моделирования.

На данный момент нами разрабатывается методика построения суррогатных моделей как для собственно алгоритмов типа RED, так и для произвольных стохастических одношаговых процессов.

\section{VIII. ЗАКЛЮЧЕНИЕ}

Авторы попытались обрисовать концепцию мультимодельного подхода к исследованию физических и технических систем на примере взаимодействующих протокола ТСР и алгоритма активного управления трафиком типа RED. Данное исследование находится в русле исследований стохастических моделей в науке и технике.

Мультимодельный подход позволяет повысить эффективность исследование явления, рассмотреть его с разных сторон и создать эффективные программные комплексы.

\section{БЛАГОДАРНОСТИ}

Публикация подготовлена при поддержке Программы РУДН «5-100» и при финансовой поддержке РФФИ в рамках научного проекта № 19-01-00645.

[1] Floyd S., Jacobson V. Random Early Detection Gateways for Congestion Avoidance // IEEE/ACM Transactions on Networking. - 1993. - Vol. 1, no. 4. - P. 397-413.

[2] Misra V., Gong W.-B., Towsley D. Stochastic Differential Equation Modeling and Analysis of TCP-Windowsize Behavior // Proceedings of PERFORMANCE. - 1999. - Vol. 99.

[3] Misra V., Gong W.-B., Towsley D. Fluid-Based Analysis of a Network of AQM Routers Supporting TCP Flows with an Application to RED // ACM SIGCOMM Computer Communication Review. - 2000. - 10. - Vol. 30, no. 4. - P. 151-160.

[4] Hollot C. V. V., Misra V., Towsley D. A Control Theoretic Analysis of RED // Proceedings IEEE INFOCOM 2001. Conference on Computer Communications. Twentieth Annual Joint Conference of the IEEE Computer and Communications Society (Cat. No.01CH37213). - Vol. 3. - IEEE, 2001. - P. 1510-1519.

[5] Геворкян М. Н., Демидова А. В., Велиева Т. Р., Королькова А. В., Кулябов Д. С., Севастьянов Л. А. Реализация метода стохастизации одношаговых процессов в системе компьютерной алгебры // Программирование. - 2018. № 2. - С. 18-27. - $\operatorname{arXiv~:~1805.03190.~}$

\footnotetext{
1 Заметим, что такого типа модели известны многим исследователям. Когда задействована только одна расчётная переменная, процесс построения суррогатной модели называется подгонкой кривой
} 
[6] Hnatič M., Eferina E. G., Korolkova A. V., Kulyabov D. S., Sevastyanov L. A. Operator Approach to the Master Equation for the One-Step Process // EPJ Web of Conferences. - 2016. - Vol. 108. - P. 02027. - arXiv : 1603.02205.

[7] Korolkova A. V., Eferina E. G., Laneev E. B., Gudkova I. A., Sevastianov L. A., Kulyabov D. S. Stochastization Of One-Step Processes In The Occupations Number Representation // Proceedings 30th European Conference on Modelling and Simulation. - 2016. - 6. - P. 698-704.

[8] Korolkova A. V., Kulyabov D. S., Velieva T. R., Zaryadov I. S. Essay on the study of the self-oscillating regime in the control system // 33 European Conference on Modelling and Simulation, ECMS 2019 / Ed. by M. Iacono, F. Palmieri, M. Gribaudo, M. Ficco. - Vol. 33 of Communications of the ECMS. - Caserta : European Council for Modelling and Simulation, 2019. - 6. - P. 473-480.

[9] Velieva T. R., Kulyabov D. S., Korolkova A. V., Zaryadov I. S. The approach to investigation of the the regions of self-oscillations // Journal of Physics: Conference Series. - 2017. - 12. — Vol. 937. — P. 012057.1-8.

[10] Велиева Т. Р., Королькова А. В., Кулябов Д. С., Сантуш Б. А. Модель управления очередями на маршрутизаторах // Вестник РУДН. Серия «Математика. Информатика. Физика». - 2014. - Т. 2. - С. 81-92.

[11] Velieva T. R., Korolkova A. V., Kulyabov D. S. Designing Installations for Verification of the Model of Active Queue Management Discipline RED in the GNS3 // 6th International Congress on Ultra Modern Telecommunications and Control Systems and Workshops (ICUMT). - IEEE Computer Society, 2015. - P. 570-577. — arXiv : 1504.02324.

[12] Welsh C. GNS3 network simulation guide. - PACKT Publisher, 2013. - 154 p. — ISBN: 1782160809.

[13] Issariyakul T., Hossain E. Introduction to Network Simulator NS2. - Boston, MA : Springer US, 2012. - 510 p. - ISBN: $978-$ 1-4614-1405-6.

[14] Altman E., Jiménez T. NS Simulator for Beginners // Synthesis Lectures on Communication Networks. - 2012. - 1. Vol. 5, no. 1. - P. 1-184.

[15] Welch B., Jones K. Practical Programming in Tcl and Tk. - 4th edition. - Prentice Hall, 2003. - 960 p. - ISBN: 9780130385604 .

[16] Nadkarni A. P. The Tcl Programming Language: A Comprehensive Guide. - CreateSpace Independent Publishing Platform, 2017. - 668 p. - ISBN: 978-1548679644

[17] Velieva T. R., Korolkova A. V., Kulyabov D. S., Abramov S. A. Parametric study of the control system in the TCP network // 10th International Congress on Ultra Modern Telecommunications and Control Systems. - Moscow, 2019. P. 334-339.

[18] Velieva T. R., Korolkova A. V., Demidova A. V., Kulyabov D. S. Software Package Development for the Active Traffic Management Module Self-oscillation Regime Investigation // Contemporary Complex Systems and Their Dependability: Proceedings of the Thirteenth International Conference on Dependability and Complex Systems DepCoS-RELCOMEX, July 2-6, 2018, Brunów, Poland / Ed. by W. Zamojski, J. Mazurkiewicz, J. Sugier, T. Walkowiak, J. Kacprzyk. - Cham : Springer International Publishing, 2019. - Vol. 761 of Advances in Intelligent Systems and Computing. - P. 515-525.

[19] Fritzson P. Principles of Object-Oriented Modeling and Simulation with Modelica 2.1. — Wiley-IEEE Press, 2003. — 939 p. ISBN: 0-471-471631.

[20] Fritzson P. Introduction to Modeling and Simulation of Technical and Physical Systems with Modelica. - Hoboken, NJ, USA : John Wiley \& Sons, Inc., 2011. — ISBN: 9781118094259.

[21] Velieva T. R., Eferina E. G., Korolkova A. V., Kulyabov D. S., Sevastianov L. A. Modelica-based TCP simulation // Journal of Physics: Conference Series. - 2017. - 1. - Vol. 788, no. 100. - P. 012036.1-7.

[22] Apreutesey A.-M. Y., Korolkova A. V., Kulyabov D. S. Modeling RED algorithm modifications in the OpenModelica // Proceedings of the Selected Papers of the 9th International Conference "Information and Telecommunication Technologies and Mathematical Modeling of High-Tech Systems" (ITTMM-2019), Moscow, Russia, April 15-19, 2019 / Ed. by D. S. Kulyabov, K. E. Samouylov, L. A. Sevastianov. - Vol. 2407 of CEUR Workshop Proceedings. - Moscow, 2019. - 4. - P. 5-14.

[23] Korolkova A. V., Velieva T. R., Abaev P. A., Sevastianov L. A., Kulyabov D. S. Hybrid Simulation Of Active Traffic Management // Proceedings 30th European Conference on Modelling and Simulation. - 2016. - 6. - P. 685-691.

[24] Jin Y. Surrogate-assisted evolutionary computation: Recent advances and future challenges // Swarm and Evolutionary Computation. - 2011. - Vol. 1, no. 2. - P. 61-70.

[25] Sevastianov L. A., Sevastianov A. L., Ayrjan E. A., Korolkova A. V., Kulyabov D. S., Pokorny I. Structural Approach to the Deep Learning Method // Proceedings of the 27th Symposium on Nuclear Electronics and Computing (NEC-2019) / Ed. by V. Korenkov, T. Strizh, A. Nechaevskiy, T. Zaikina. - Vol. 2507 of CEUR Workshop Proceedings. - Budva, 2019. 9. - P. 272-275. 